\title{
Peningkatan Kemampuan Menulis Teks Drama dengan Pendekatan Kontekstual Komponen Pemodelan di Kelas XI SMAN 9 Gowa
}

\author{
Asis Nojeng1
}

Amal Akbar ${ }^{2}$

Suparmin $^{3}$

\author{
12Pendidikan Bahasa dan Sastra Indonesia Fakultas keguruan dan Ilmu \\ Pendidikan Universitas Muhammadiyah Makassar \\ ${ }^{3}$ SMA Negeri 9 Gowa \\ 1asisnojeng@unismuh.ac.id \\ 2amalakbar@unismuh.ac.id \\ ${ }^{3}$ suparmin@gmail.com
}

\begin{abstract}
Abstrak
Penelitian ini bertujuan untuk meningkatkan kemampuan menulis teks drama dengan pendekatan kontekstual komponen pemodelan dalam meningkatkan hasil belajar khususnya menulis teks drama pada siswa kelas XI SMA Negeri 9 Gowa. penelitian ini merupakan penelitian tindakan kelas yang pelaksanaannya terdiri dari beberapa siklus yang dimulai dari perencanaan. Kemampuan menulis teks drama merupakan kemampuan yang penyajiannya logis dan objektif sesuai dengan benda, situasi keadaan yang diamati. hasil analisis penelitian dan pembahasan penelitian tindakan kelas ini dapat disimpulkan sebagai berikut. Kemampuan menulis teks drama kelas XI SMAN 9 Gowa Kecamatan Somba Opu Kabupaten Gowa setelah mengikuti pembelajaran menulis teks drama dengan menggunakan teks drama sebagai model dalam pembelajaran melalui pendekatan kontekstual komponen pemodelan mengalami peningkatan. Hasil data dari tes prasiklus menunjukkan skor rata-rata kelas sebesar 58,04 dan pada siklus I rata-rata kelas sebesar 67. Hal ini berarti menunjukkan ada peningkatan sebesar 9. Pada siklis II menghasilkan skor rata-rata kelas sebesar 80,2. Hal ini menunjukkan adanya peningkatan dari siklus I ke siklus II sebesar 13,2\%. Jadi terjadi peningktan keterampilan menulis drama dengan pendektan kontekstual pemodelan.
\end{abstract}

Kata kunci: Menulis Teks Drama, Pendekatan Kontekstual, Komponen pemodelan

\section{Pendahuluan}

Menyimak adalah suatu proses kegiatan mendengarkan lambang-lambang lisan dengan penuh perhatian, pemahaman, apresiasi, serta interpretasi untuk memperoleh informasi, menangkap isi atau pesan serta memahami makna komunikasi yang telah disampaikan oleh sang pembicara melalui ujaran atau bahasa lisan. Menyimak membutuhkan konsentrasi tinggi agar pesan yang disampaikan dapat kita tangkap dengan baik. Pelibatan beberapa indera sangat dibutuhkan dalam menyimak. (Alfani et al., 2012; Indrawati et al., 2021) . 
Berbicara merupakan instrumen yang mengungkapkan kepada penyimak hampirhampir secara langsung apakah sang pembicara memahami atau tidak baik bahan pembicaraannya maupun para penyimaknya; apakah dia bersikap tenang serta dapat menyesuaikan diri atau tidak, pada saat dia mengomunikasikan gagasan-gagasannya; dan apakah dia waspada serta antusias atau tidak. menyatakan bahwa membaca adalah suatu proses yang dilakukan serta dipergunakan oleh pembaca untuk memperoleh pesan, yang hendak disampaikan oleh penulis melalui media kata-kata/bahasa tulis(Zainur et al., 2020)

Seperti halnya dengan menyimak dan berbicara, proses pemerolehan berbahasa yang lain sangat menunjang aktivitas dalam pembelajaran. Kemampuan menulis sebaiknya telah diberlakukan ketika siswa berada di jenjang sekolah dasar, hal ini menjadi pijakan awal bagi siswa untuk melangkah ke pendidikan yang lebih tinggi mulai dari Sekolah Menengah Pertama (SMP), Sekolah Menengah Atas (SMA) hingga ke jenjang perguruan tinggi (Susanto \& Andik, 2020).

Kemampuan menulis diharapkan mampu memberikan stimulus kepada anak agar dapat mengolah daya nalar dan daya bayang. Olehnya itu, keterampilan menulis harus di ajarkan sejak dini. Memiliki keterampilan menulis siswa dapat mengembangkan dan menuangkan gagasan dan pengalamannya dalam berbagai macam bentuk, salah satunya adalah cerita dalam bentuk drama (Khairi, 2020)

Dalam menulis diperlukan adanya suatu bentuk ekspresi gagasan yang berkesinambungan dan mempunyai urutan logis.Hal ini dapat diwujudkan dalam penggunaan kosa kata dan tata bahasanya, sehingga dapat menggambarkan atau menyajikan informasi yang diekspresikan secara jelas (Beer \& McMurrey, 2019; Zapata, 2020)

Kenyataan menunjukkan bahwa kemampuan dalam hal menulis, siswa belum sepenuhnya menguasai. Siswa beranggapan bahwa menulis adalah sesuatu yang sulit untuk dilaksanakan. Bahkan, mereka menganggap bahwa menulis itu sangat membosankan. Kendala tersebut menunjukkan kurangnya minat siswa dalam hal menulis. Seperti halnya menulis drama, siswa masih terkendala dalam memulai atau mengumpulkan ide, juga terkendala menuangkan ide dalam sebuah bentuk cerita. Olehnya itu, guru harus mencari cara untuk meningkatkan kemampuan menulis bagi siswa (Mufidah \& Rohima, 2020).

Ketika siswa menguasai kemampuan menulis, maka siswa tersebut tidak mendapat rintangan saat mengikuti pembelajaran. Pembelajaran kontekstual dapat dikatakan sebagai sebuah pendekatan pembelajaran yang menunjukkan kondisi alamiah dari pengetahuan. Melalui hubungan di dalam dan di luar ruang kelas, suatu pendekatan pembelajaran kontekstual menjadikan pengalaman lebih relevan dan berarti bagi siswa dalam membangun pengetahuan yang akan mereka terapkan dalam pembelajaran seumur hidup (Verawati, 2017).

Metode yang dapat digunakan untuk membuat naskah/teks drama yakni dengan melakukan pengamatan secara langsung secara objektif agar dapat memberikan penyajian yang logis (Indramawan, 2021).

Penelitian tentang peningkatan kemampuan menulis teks drama dengan pendekatan kontekstual pernah dilakukan oleh (Muyassaroh, 2007) dengan judul Peningkatan Kemampuan Menulis Teks Drama dengan Pendekatan Kontekstual Komponen Pemodelan pada Siswa kelas VIII E SMP Negeri 3 Ungaran. Hasil dari 
penelitian tersebut menunjukkan adanya peningkatan terhadap siswa peningakatan kemampuan menulis teks drama dan perubahan perilaku siswa kelas VIII E SMP Negeri 3 Ungaran setelah mengikuti pembelajaran menulis teks drama.

Penelitian serupa juga pernah dilakukan oleh (Badelah, 2021) yang berjudul peningkatan kemampuan menulis teks drama dengan menggunakan media cerpen siswa kelas VIII E SMP Negeri 2 Sakra tahun pelajaran 2020/2021. Dengan menggunakan media cerpen dapat meningkatkan mutu proses hasil belajar menulis teks drama siswa kelas VIII E SMP Negeri 2 Sakra.

\section{Kerangka Teori}

Menulis merupakan menurunkan atau melukiskan lambang-lambang grafik yang melukiskan suatu bahasa yang dapat dimengerti oleh seseorang, sehingga orang lain dapat membaca lambang grafik tersebut kalau mereka memahami bahasa dan gam baran grafik itu (Wati \& Santosa, 2019).

Menulis adalah kemampuan mengungkapkan gagasan, pikiran, pendapat, pengetahuan, dan pengalaman hidup dalam bahasa tulis yang jelas, konsisten, nyaman, dan dapat dipahami (Sakubun, 2019).

Menulis merupakan kemampuan mengungkapkan gagasan, pikiran, pendapat, pengetahuan, dan pengalaman hidup dalam bahasa tulis vang ielas, konsisten, nvaman, dan mudah dipahami. Menulis adalah tindakan pengakuan dan ekspresi. Kognisi berarti bahwa melalui kegiatan menulis, kita dapat mengenali, mengevaluasi, mereproduksi secara kritis, dan menggunakan dalam kehidupan nvata berbagai hal vang ditemukan dalam tulisan kreatif orang lain dengan cara vang unik. Hal itu diungkapkan dalam arti bahwa sava dapat mengungkapkan berbagai pengalaman dan hal-hal bermakna dalam diri sava, dan itu disampaikan kepada orang lain lewat tulisan yang kreatif sebagai hal yang bermakna. Salah satu teks yang kreatif adalah naskah (Tabelessy, 2019)

Menulis merupakan kegiatan yang produktif dan ekspresif untuk mengungkapkan ide, pikiran, gagasan, dan pengetahuan. Kegiatan menulis ini, maka penulis harus terampil memanfaatkan grafologi, struktur bahasa, dan kosakata. Sebagai kegiatan produktif karena kegiatan menulis menghasilkan tulisan, sebagai kegiatan yang ekspresif karena kegiatan menulis adalah kegiatan yang mengungkapkan ide, gagasan, pikiran, dan pengetahuan penulis kepada pembaca (Destiana, 2019)

Menulis adalah kemampuan mengungkapkan gagasan, pikiran, pendapat, pengetahuan, dan pengalaman hidup dalam bahasa tulis yang jelas, runtut, nyaman, dan mudah dipahami orang lain. Menulis merupakan kegiatan ekspresif yang mengungkapkan rasa syukur. Syukur artinya dengan menulis, orang dapat mengenali, menghargai, dan secara kritis mereproduksi apa yang terkandung dalam tulisan kreatif orang lain dan menggunakannya dalam kehidupan nyata. .. Diekspresikan dalam arti bahwa Anda dapat mengungkapkan berbagai pengalaman dan hal-hal yang bermakna dalam diri Anda dan disampaikan kepada orang lain untuk menyampaikan makna melalui menulis kreatif. Salah satu teks kreatif adalah teks drama. Berbagai pengertian teater di atas mencerminkan bahwa teater merupakan opera yang hanya menekankan pada dimensi teater. Drama ditulis untuk tujuan pertunjukan, tetapi itu tidak berarti bahwa semua karya yang ditulis oleh penulis harus dilakonkan. Lakon itu dipahami, dipahami, dan dihargai, meskipun tidak dipentaskan.

Menulis teks drama harus mampu merumuskan tema dan ide agar dapat mendiskripsikan segala unsur yang ada di dalam teks/naskah drama. Unsur yang dimaksud yakni penokohan dan penamaan tokoh, membuat dialog, menjalin alur dan penentuan plot/latar(D. N. Hutagaol, 2020).

Keterampilan menulis jika dikaitkan dengan pembelajaran kontekstual maka akan memberikan pengalaman belajar bagi siswa juga bagi guru. Pembelajaran kontekstual merupakan salah satu pembelajaran yang menekankan bahwa siswa harus mengetahui implementasi dari pengetahuan yang diperolehnya sehingga pengetahuan tersebut akan bermakna bagi siswa (K. Hutagaol, 2013). 
Pembelajaran kontekstual adalah suatu pendekatan pembelajaran yang menekankan pada proses keterlibatan siswa secara penuh untuk menemukan materi yang dipelajari dan menghubungkannya dengan situasi kehidupan nyata sehingga mendorong siswa untuk dapat menerapkannya pada kehidupan mereka (Silalahi, 2011)

Dari hasil pengamatan, ternyata rata-rata siswa kelas XI SMAN 9 Gowa mengeluhkan materi pembelajaran menulis dan juga materi tentang menulis naskah/teks drama. Hal ini disebabkan karena metode yang digunakan guru berkisar pada penjelasan semata atau hanya menggunakan metode ceramah. Kurangnya minat belajar siswa karena tidak mendapatkan gambaran yang jelas tentang menulis teks drama yang sesuai (Oflaz, 2019).

Meskipun telah mempelajari keterampilan dasar komposisi teater, mereka masih menghadapi berbagai kendala. Hal ini sejalan dengan informasi yang diperoleh dari guru di bidang bahasa Indonesia, menunjukkan bahwa siswa tidak mampu menulis lakon dengan benar dan mau menulis lakon ketika diberi tugas dari guru. Ini adalah tema drama. Gurulah yang memutuskan untuk melakukannya. Untuk mencapai kemampuan dasar menulis naskah yang memuaskan, penulis mengambil pendekatan kontekstual dengan memodelkan komponen-komponennya. Berdasarkan konteks di atas, maka pertanyaan yang akan dibahas adalah "Bagaimana Meningkatkan Penulisan Drama Menggunakan Pendekatan Kontekstual pada Komponen Model di Kelas" SMA Negeri 9 Gowa.

\section{Metode}

\section{Desain Penelitian}

Dalam penelitian ini, peneliti menggunakan penelitian tindakan kelas (PTK) menggunakan penelitian tindakan yang merupakan acuan dari model PTK Kurt Lewin. Konsep PTK Kurt Lewin terdiri dari empat komponen yaitu perencanaan (planning), tindakan (acting), pengamatan (observing), dan refleksi (reflecting). Hubungan keempat komponen tersebut dipandang sebagai suatu siklus. Desain Kurt Lewin dapat dilihat dalam gambar sebagai berikut:

Penelitian tindakan kelas, seperti dalam gambar berikut.

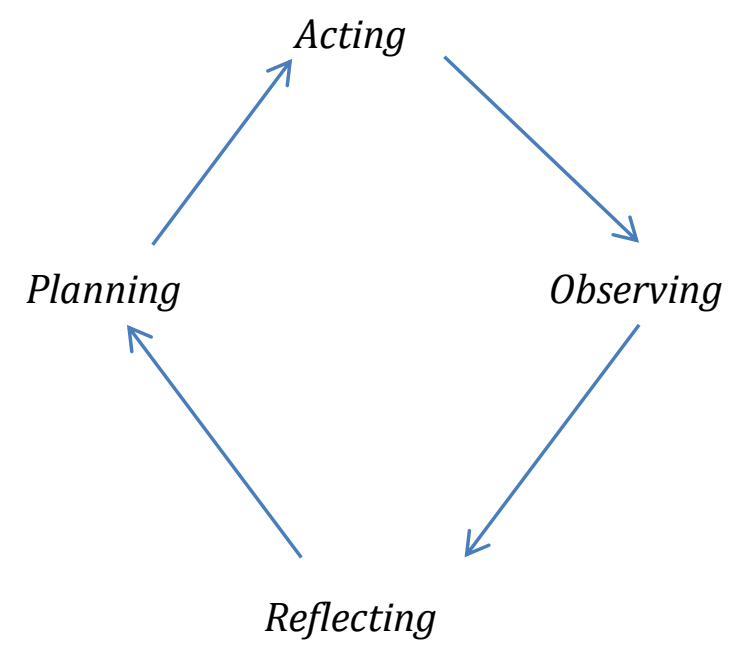

\section{Gambar 1 Alur PTK}

Tindakan dalam penelitian ini, dilakukan dalam dua siklus.Siklus I yang meliputi perencanaan, tindakan, pengamatan, dan refleksi merupakan awal kegiatan penelitian untuk mengetahui kondisi awal siswa mengenai kemampuan siswa dalam pembelajaran 
keterampilan menulis drama melalui metode kontekstual elemen pemodelan. Dengan adanya refleksi yang meliputi analisis dan penelitian pada proses tindakan pada siklus I, akan muncul penelitian baru guna mengatasi permasalahan tersebut sehingga memerlukan perencanaan ulang, tindakan ulang, pengamatan ulang, dan refleksi ulang pada siklus II.

1). Siklus I

Siklus ini dimaksudkan untuk melakukan pembelajaran dan penulisan teks drama menggunakan pendekatan kontekstual komponen pemodelan. Selain itu, siklus I digunakan sebagai pembanding dengan pembelajaran pada siklus II. Langkah-langkah yang digunakan pada siklus I adalah sebagai berikut:

\section{a. Perencanaan}

Pada siklus I peneliti memasukkan 1) judul, yang meliputi jenis mata pelajaran, jenjang pendidikan, tema, kelas, semester, alokasi waktu, 2) skenario pembelajaran meliputi kegiatan pendahuluan, kegiatan inti, penutup, 3) scenario pembelajaran termasuk alat dan bahan 4) strategi pembelajaran, 5) sarana dan sumber pembelajaran.

\section{b. Tindakan}

Langkah pertama dalam fase perencanaan ini adalah mengorganisir kegiatan kognitif singkat oleh guru yang menceritakan kisah-kisah yang berhubungan dengan drama, mengajukan pertanyaan, menetapkan tujuan pembelajaran, dan mengumumkan keterampilan yang perlu diperoleh siswa. Kegiatan selanjutnya guru memberikan materi kemudian guru meminta siswa untuk membentuk kelompok kecil. Selanjutnya, mintalah siswa untuk mendiskusikan isi dari pekerjaan tersebut. Langkah selanjutnya, guru meminta siswa untuk mendiskusikan topik yang ditulis oleh setiap anggota kelompok dan menulis drama tentang topik yang mereka diskusikan secara individu. Di akhir pelajaran, guru dan siswa meninjau apa yang mereka pelajari dan menarik kesimpulan

\section{c. Observasi}

Peneliti berpartisipasi dalam perilaku siswa dalam proses pembelajaran, terutama sikap siswa untuk berpartisipasi dalam pembelajaran dengan alat tulis, aktivitas siswa mendengarkan, dan menanggapi pendapat teman dan bergabung. Pelajari cara menulis drama dari awal hingga akhir.

\section{d. Refleksi}

Peneliti menganalisis observasi berdasarkan performa menulis teks drama dan perilaku belajar siswa saat menulis teks drama. Sejauh mana siswa berinteraksi secara aktif antara guru dan siswa, atau antara siswa dan siswa, untuk memvalidasi kemampuan intelektual siswa dalam memahami teks drama. Berdasarkan analisis ini, dapat dilihat bahwa beberapa siswa masih mengalami kesulitan mengidentifikasi kepribadian dan konflik yang jelas. Menganalisis hasil kegiatan menulis teks drama pada siklus pertama untuk membandingkannya dengan siklus tindakan kedua. 


\section{2) Siklus II}

Siklus II bertujuan untuk meningkatkan kemampuan siswa dalam menulis teks drama dan membantu menentukan keterlibatan siswa dalam proses pembelajaran menulis drama. Mengevaluasi proses dan hasil ini merupakan bagian integral dari penelitian yang digunakan sebagai tolak ukur untuk meningkatkan kinerja siswa dan menentukan perubahan perilaku belajar siswa dalam skrip.

\section{a. Perencanaan}

Pada siklus II peneliti menyusun; 1) jenis mata pelajaran, jenjang pendidikan, mata pelajaran, kelas, semester, alokasi waktu, 2) kegiatan persiapan, kegiatan inti, skenario pembelajaran termasuk penutup, 3) alat dan bahan, 4) strategi pembelajaran. , 5) Struktur dan sumber belajar, 6) Jenis penelitian.

\section{b. Tindakan}

Tahap pertama Siklus II tidak jauh berbeda dengan Siklus 1. Setelah diketahui kendala atau kekurangan yang terkait dengan Siklus I, peneliti akan berusaha memperbaiki pada Siklus II agar kesalahan yang sama tidak terulang pada Siklus I. Siswa masih mengalami kesulitan mendefinisikan kepribadian mereka sendiri dan mengidentifikasi konflik secara jelas dan tidak ambigu. Bagian yang masih membingungkan siswa adalah perhatian peneliti yang diamati pada siklus II.

Kegiatan tahap kedua berjalan seperti siklus pertama, namun pada siklus kedua peneliti lebih fokus pada masalah karakteristik dan persaingan. Pada siklus II peneliti menyajikan model dalam bentuk drama, guru membimbing siswa untuk bertindak, memperhatikan kesalahan siswa terlebih dahulu. Langkah ketiga adalah guru menutup dan menginformasikan kepada siswa tentang manfaat menulis drama.

\section{c. Refleksi}

Pada siklus kedua, mengamati aktivitas siswa. Analisis nilai siswa meliputi sejauh mana siswa secara aktif dan antusias berpartisipasi dalam kegiatan penulisan naskah drama. Setelah menganalisis siklus II, peneliti membandingkan hasil siklus I dengan hasil siklus II. Menurut survei yang dilakukan oleh siswa yang menulis scenario/teks drama, subjek survei ini adalah SMAN 9 Gowa Kelas XI. Salah satu kegiatan penelitian yang penting adalah mengumpulkan data yang diperlukan. Hal ini karena hasil yang menentukan untuk penelitian. Dua metode pengumpulan data yang digunakan dalam penelitian ini: eksperimental dan non-eksperimental.

\section{Teknik Tes}

Data untuk penelitian ini diperoleh dengan menggunakan tes dua kali yang digunakan sebagai tolak ukur untuk meningkatkan peluang siswa berhasil menulis skrip/teks drama. Setelah belajar menulis skrip/teks drama, siswa diberi tugas, tesnya berupa skrip/teks drama.

\section{Teknik Nontes}

Teknik nontes alat penilaian yang dipergunakan untuk mendapatkan informasi tentang keadaan isi tes tanpa dengan alt tes.Teknik nontes dipergunakan untuk mendapatkan data yang tidak secara langsung berkaitan dengan tingkah laku kognitif.Instrument ini bewujud observasi dan dokumentasi foto. 


\section{Teknik Analisis Data}

Teknik analisis data dilakukan secara kualitatif dan kuantitatif. Pendekatan kualitatif ini didasarkan pada data non-eksperimental: observasi, wawancara, catatan harian dan dokumen foto. Data yang dikumpulkan pada siswa akan dikelompokkan sesuai dengan aspek yang diselidiki. Penelitian ini, di sisi lain, menggunakan pendekatan kuantitatif untuk menganalisis data dari hasil dua tes, satu di akhir siklus pertama dan yang lainnya di akhir siklus kedua. Proses perhitungan melibatkan penghitungan poin/skor yang diperoleh siswa dan penghitungan poin/skor, penghitungan poin/skor kumulatif dari semua aspek.

$$
\begin{gathered}
\text { Skor rata-rata dengan rumus. } \\
\qquad \mathrm{M}=\frac{\Sigma X}{N} \\
\text { Keterangan: } \mathrm{M}=\text { Nilai rata }- \text { rata } \\
\Sigma X=\text { Jumlah keseluruhan nilai } \\
\mathrm{N}=\text { Jumlah siswa }
\end{gathered}
$$

Hasil hitungan siswa pada setiap tes tersebut kemudian peneliti membandingkan antara Siklus I dan Siklus II. Hasil tersebut memberikan wawasan tentang perkembangan keterampilan siswa setelah mengikuti pembelajaran menulis teks drama melalui pendekatan kontekstual dengan menggunakan komponen modeling.

\section{Hasil}

Hasil dan Pembahasan tes penelitian fokus pada pemerolehan skor yang dicapai siswa ketika diberi tugas untuk menulis teks drama. Aspek-aspek yang dinilai dalam kemampuan menulis teks drama meliputi lima aspek, yaitu aspek tema, aspek setting, aspek alur, aspek penokohan atau perwatakan, dan aspek bahasa. Pembahasan hasil nontes perpedoman pada empat bentuk instrument penelitian yaitu lembar observasi dan dokumentasi foto.

Peneliti menginisiasi pembelajaran menulis naskah drama dengan model pembelajaran menulis naskah drama melalui pendekatan kontekstual dengan pemodelan komponen Siklus I dan Siklus II. Peneliti kemudian mempersepsikan dengan bertanyatanya tentang kondisi siswa dan menarik perhatian siswa pada penjelasan yang peneliti berikan. Peneliti kemudian meminta siswa untuk membentuk kelompok kecil yang terdiri dari empat sampai lima orang. Para peneliti kemudian membagikan naskah drama kepada semua siswa. Siswa mulai membaca dan mengamati teks atau naskah drama, kemudian berdiskusi untuk menemukan unsur-unsur yang terdapat di dalam teks tersebut. Peneliti kemudian meminta perwakilan kelompok untuk membagikan hasil diskusinya. Peneliti meminta siswa mendiskusikan topik yang akan digunakan sebagai teks drama. Selanjutnya, peneliti meminta siswa untuk menulis teks drama tersebut.

Berdasar dari hasil tes menulis teks drama tersebut, peneliti mengetahui kemampuan menulis teks drama Kelas XI SMAN 9 Gowa Kabupaten Gowa pada siklus II.

Hasil tes menulis teks drama prasiklus, siklus I, dan siklus II dapat dilihat pada tabel 27 berikut ini. 
Tabel 1. Peningktan Kemampuan Menulis Teks Drama Prasiklus, siklus I, dan siklus II

\begin{tabular}{cccccccc}
\hline No & Aspek & \multicolumn{3}{c}{ Nilai Rata - Rata Kelas } & \multicolumn{3}{c}{ Peningkatan } \\
& & P & SI & SII & P-SI & SI-SII & P-SII \\
\hline 1 & I & 7,7 & 8,1 & 8,9 & 0,4 & 0,8 & 1,2 \\
2 & II & 7,8 & 8,6 & 8,8 & 0,8 & 0,2 & 1 \\
3 & III & 10 & 13,9 & 22,5 & 3,9 & 8,6 & 12,5 \\
4 & IV & 10 & 10,3 & 11,5 & 0,3 & 1,2 & 1,5 \\
5 & V & 11,04 & 11,3 & 11,5 & 0,3 & 0,2 & 0,5 \\
6 & VI & 6,1 & 6,6 & 7,9 & 0,5 & 1,3 & 1,8 \\
7 & VII & 5,4 & 8,2 & 9,1 & 2,8 & 0,9 & 3,7 \\
\hline Rata-rata & $\mathbf{5 8 , 0 4}$ & $\mathbf{6 7}$ & $\mathbf{8 0 , 2}$ & $\mathbf{9}$ & $\mathbf{1 3 , 2}$ & $\mathbf{2 2 , 2}$ \\
\hline
\end{tabular}

Keterangan: $\mathrm{I}=$ tema, $\mathrm{II}=$ setting, $\mathrm{III}=$ alur, $\mathrm{IV}=$ penokohan, $\mathrm{V}=$ bahasa, $\mathrm{VI}=$ teks berbentuk teks drama dan disajikan dalam satu babak.

Berdasarkan rekapitulasi data hasil tes kemampuan menulis teks drama dari prasiklus, siklus I, dan siklus II dapat dijelaskan bahwa kemampuan menulis teks drama siswa pada setiap aspek penelitian menulis teks drama mengalami peningkatan. Berikut adalah uraian tabel 1.

Hasil prasiklus menunjukkan bahwa rata-rata kemampuan menulis teks drama sebesar 58,04. Dari skor rata-rata tersebut, dapat dilihat bahwa kemampuan menulis teks drama siswa masih berada pada kategori kurang atau masih dinilai rendah karena berada pada rentang nilai 0-58. Rata-rata tersebut berasal dari jumlah skor rata-rata masingmasing aspek. Pada prasiklus, rata-rata untuk masing-masing aspek adalah sebagai berikut: (1) aspek tema sebesar 7,7; (2) aspek setting sebesar 7,8; (3) aspek konflik sebesar 10; (4) aspek penokohan sebesar 10; (5) aspek bahasa sebesar 11,04; (6) aspek tes berbentuk teks drama dan disajikan dalam satu babak sebesar 6,1; dan (7) aspek kemungkinan dipentaskan sebesar 5,4 Siswa masih belum mampu menulis naskah drama karena tidak mengetahui bentuk teks drama dan pendekatan serta strategi yang digunakan guru kurang tepat. Ketika belajar menulis drama untuk anak prasekolah, guru tidak mengambil drama sebagai model untuk dipelajari. Selain itu, guru tidak menerapkan pendekatan kontekstual komponen model, sehingga siswa kurang tertarik dengan cara menulis naskah.

Hasil tes menulis drama siklus I dengan rata-rata nilai klasikal 67 tergolong dalam kategori cukup, karena berada pada rentang nilai 65-74. Meskipun termasuk dalam kategori cukup, tetapi ada beberapa siswa menacapai nilai rata-rata yang sesuai dengan batas ketuntasan yang sudah ditentukan, yaitu 65 . Nilai rata-rata tersebut berasal dari skor rata-rata tiap aspek pada penilaian menulis teks drama.

Pada aspek tema rata-rata skor yang dicapai siswa sebesar 8,1 sehingga tergolong dalam kategori baik dan mengalami peningkatan sebesar 0,4 atau sebesar 9 dari skor rata-rata prasiklus. Hasil tersebut menunjukkan bahwa secara umum siswa sudah mampu menentukan tema yang relevan dengan keperluan pementasan.

Pada aspek setting, rata-rata skor yang dicapai siswa sebesar 8,6 atau termasuk kategori baik. Dalam hal ini, siswa mengalami kemajuan dengan kalata lain mengalami peningkatan sebesar 0,8 atau sebesar 9 dari skor rata-rata prasiklus. Hasil tersebut menunjukkan bahwa sebagian siswa sudah mampu mendeskripsikan setting dengan rinci, jelas, dan hidup. 
Dari aspek konflik rata-rata skor yang dicapai oleh siswa sebesar 13,9 atau termasuk dalam kategori kurang dan mengalami peningkatan sebesar 3,9 atau sebesar 9 dari skor rata-rata prasiklus. Hasil tersebut menunjukkan bahwa sebagian siswa sudah mampu menciptakan konflik yang tajam dan jelas.

Pada aspek penokohan rata-rata skor yang dicapai oleh siswa sebesar 10,3 atau termasuk dalam kategori baik. Dalam hal ini, siswa mengalami peningkatan sebesar 0,3 dari skor rata-rata prasiklus. Hasil tersebut menunjukkan bahwa siswa sudah mampu menggambarkan karakter tokoh dengan jelas.

Aspek bahasa rata-rata skor yang dicapai oleh siswa sebesar 11.3 atau termasuk kategori cukup dan mengalami peningkatan sebesar 0,3 dari skor rata-rata prasiklus. Hasi tersebut menunjukkan bahwa sebagian siswa sudah mampu dalam menggunakan bahasa yang dapat menggambarkan karakter tokoh yang berbeda.

Aspek teks berbentuk teks drama dan disajikan dalam satu babak rata-rata skor yang dicapai oleh siswa sebesar 6,6 atau masih dalam keadaan cukup dan mengalami peningkatan sebesar 0,5 dari skor rata-rata prasiklus. Hasil tersebut menunjukkan bahwa sebagian siswa belum mampu menghasilkan bentuk teks drama yang sesuai dengan kaidah penulisan teks drama.

Dari aspek ada kemungkinan untuk dipentaskan rata-rata skor yang dicapai oleh siswa sebesar 8,2 atau masih dalam kategori baik dan mengalami peningkatan sebesar 2,8 dari skor rata-rata prasiklus. Hasil tersebut menunjukkan bahwa sebagian siswa belum mampu mengahsilkan teks drama yang memiliki kemungkinan untuk dipentaskan.

Dengan demikian, dapat disimpulkan bahwa kemampuan siswa dalam menulis teks drama siklus I mengalami peningkatan sebesar 9 dari skor rata-rata prasiklus. Hasil tes menulis teks drama siklus II berhasil mencapai nilai sebesar 80,2 atau masuk kategori baik karena berada pada rentang nilai 75-84. Pencapaian skor tersebut berarti sudah memenuhi batas tuntas yang ditetapkan. Dengan demikian, tindakan siklus III tidak perlu dilakukan. Hasil pemerolehan nilai dari masing-masing aspek pada siklus II dapat diuraikan sebagai berikut.

Selanjutnya, akan dipaparkan mengenai peningkatan kemampuan menulis teks drama dengan pendekatan kontekstual komponen pemodelan. Peningkatan tersebut akan dijabarkan di bawah ini:

Pada aspek tema rata-rata skor yang dicapai siswa sebesar 8,9 atau termasuk kategori sangat baik dan mengalami peningkatan sebesar 0,8 dari skor rata-rata siklus I. Hasil tersebut menunjukkan bahwa secara umum siswa sudah mampu menentukan tema yang relevan dengan keperluan pementasan. Pada aspek setting, rata-rata skor yang dicapai siswa sebesar 8,8 atau termasuk kategori baik dan mengalami peningkatan sebesar 0,2 dari skor rata-rata siklus I. hasil tersebut menunjukkan bahwa secara umum siswa sudah mampu mendeskripsikan setting secara rinci, jelas, dan hidup.

Pada aspek konflik rata-rata skor yang dicapai siswa sebesar 22,5 atau termasuk kategori sangat baik. Dalam hali ini, siswa mengalami kemajuan peningkatan sebesar 8,6 dari skor rata-rata siklus I. hasil tersebut menunjukkan bahwa secara umum siswa sudah mampu dalam menentukan konflik yang tajam dan jelas.

Pada aspek penokohan rata-rata skor siswa sebesar 11,5 atau termasuk dalam kategori baik. Dalam hal ini siswa ada peningkatan sebesar 1,2 dari skor rata-rata siklus I. hasil tersebut menunjukkan bahwa siswa sudah mampu menggambarkan karakter masing-masing tokoh yang berbeda.

Dari segi aspek bahasa rata-rata skor yang dicapai oleh siswa sebesar 11,5 atau termasuk dalam kategori baik. Dalam hal ini siswa mengalami peningkatan sebesar 0,2 
dari skor rata-rata siklus I. Hasil tersebut menunjukkan bahwa siswa sudah mampu dalam menggunakan bahasa yang dapat menggambarkan karakter tiap-tiap tokoh.

Pada aspek teks yang berbentuk teks drama kemudian disajikan dalam pertunjukan satu babak rata-rata skor yang dicapai oleh siswa sebesar 7,9 atau masih dalam kategori cukup dan mengalami peningkatan sebesar 1,3 dari skor rata-rata silkus I. hasil tersebut menunjukkan bahwa sebagian siswa sudah mampu menghasilkan bentuk teks drama yang sesuai dengan kaidah penulisan teks drama.

Pada aspek ada kemungkinan untuk dipentaskan rata-rata siswa memperoleh nilai sebesar 9,1 atau dalam kategori sangat baik dan mengalami peningkatan 0,9 dari ratarata siklus I. Hasil tersebut menunjukkan bahwa masih ada beberapa siswa yang belum mampu menghasilkan teks drama yang memiliki kemungkinan untuk dipentaskan. Akan tetapi, dalam hal ini sudah dapat dikatakan bahwa sebagian siswa sudah mampu menghasilkan teks drama yang sesuai dengan kaidah penulisan teks drama.

Dengan demikian, dapat disimpulkan bahwa kemampuan siswa dalam menulis teks drama sudah mengalami peningkatan, peningkatan dari prasiklus ke siklus I sebesar 9 peningkatan dari siklus I ke siklus II sebesar 13,2 atau dan peningkatan dari prasiklus ke siklus II sebesar 22,2.

Peningkatan kemampuan atau keterampilan siswa menulis teks drama merupakan prestasi yang membanggakan karena kemampuan menuis siswa masih kurang sebelum tindakan siklus I dan siklus II. Namun, setelah diterapkan metode skenario dengan menggunakan teks drama sebagai model dalam pembelajaran melalui pendekatan kontekstual komponen pemodelan mengalami peningkatan.

Dengan adanya peningkatan nilai rata-rata tiap aspek pada siklus I membuktikan penggunaan teks drama sebagai model pembelajaran dengan pendekatan kontekstual komponen pemodelan dapat meningkatkan kemampuan menulis teks drama siswa Kelas XI SMAN 9 Gowa Kecamatan Somba Opu Kabupaten Gowa. Oleh karena itu, penggunaan teks drama sebagai model pembelajaran menurut pendekatan kontekstual komponen pemodelan telah meningkatkan kualitas, kreativitas, produktivitas dan efisiensi belajar siswa saat menulis drama.

Hadirnya teks drama sebagai model pembelajaran dan penggunaan pendekatan kontekstual komponen pemodelan dalam pembelajaran menulis teks drama untuk siswa kelas XI SMAN 9 Gowa Kecamatan Somba Opu Kabupaten Gowa dapat membantu kelancaran, efektivitas, dan efisiensi pencapaian tujuan pembelajaran. Penggunaan teks drama dalam pembelajaran, sangat membantu dalam mengatasi kesulitan yang dihadapi siswa dalam mengidentifikasi unsur-unsur teks drama.

Sesuai dengan apa yang dikemukakan oleh tentang kelebihan menggunakan pendekatan kontekstual dapat memberikan stimulus bagi daya pikir dan daya bayang peserta didik untuk lebih mengasah lagi kemampuannya dalam hal menuangkan ide ke dalam sebuah bentuk tulisan, dalam hal ini menulis teks drama(McConnell et al., 2020)

Menggunakan pendekatan kontekstual komponen pemodelan dalam pembelajaran dapat memberikan kebebasan kepada siswa untuk mengungkapkan pendapat dan gagasannya dalam bentuk teks drama. Dengan menggunakan model yang tepat dan pemilihan pendekatan yang tepat mampu meningkatkan minat belajar siswa dan pada akhirnya kinerja dan prestasi siswa juga turut meningkat.

Peningkatan kemampuan atau keterampilan siswa menulis teks drama merupakan prestasi yang membanggakan karena kemampuan menulis siswa masih kurang sebelum tindakan siklus I dan siklus II. Namun, setelah diterapkan metode skenario dengan menggunakan teks drama sebagai model dalam pembelajaran melalui pendekatan kontekstual komponen pemodelan mengalami peningkatan. 
Dengan adanya peningkatan nilai rata-rata tiap aspek pada siklus I membuktikan penggunaan teks drama sebagai model pembelajaran dengan pendekatan kontekstual komponen pemodelan dapat meningkatkan kemampuan menulis teks drama siswa Kelas XI SMAN 9 Gowa Kecamatan Somba Opu Kabupaten Gowa. Oleh karena itu, penggunaan teks drama sebagai model pembelajaran menurut pendekatan kontekstual komponen pemodelan telah meningkatkan kualitas, kreativitas, produktivitas dan efisiensi belajar siswa saat menulis drama.

Hadirnya teks drama sebagai model pembelajaran dan penggunaan pendekatan kontekstual komponen pemodelan dalam pembelajaran menulis teks drama untuk siswa kelas XI SMAN 9 Gowa Kecamatan Somba Opu Kabupaten Gowa dapat membantu kelancaran, efektivitas, dan efisiensi pencapaian tujuan pembelajaran. Penggunaan teks drama dalam pembelajaran, sangat membantu dalam mengatasi kesulitan yang dihadapi siswa dalam mengidentifikasi unsur-unsur teks drama.

Menggunakan pendekatan kontekstual komponen pemodelan dalam pembelajaran dapat memberikan kebebasan kepada siswa untuk mengungkapkan pendapat dan gagasannya dalam bentuk teks drama. Dengan menggunakan model yang tepat dan pemilihan pendekatan yang tepat mampu meningkatkan minat belajar siswa dan pada akhirnya kinerja dan prestasi siswa juga turut meningkat (Rasyid, 2020)

Pernyataan tersebut dikuatkan oleh bukti hasil penelitian yang dilakukan oleh (Marwani, 2020) yang menunjukkan adanya peningkatan kemampuan menulis siswa pada aspek-aspek yang penting dalam menulis nasakah drama. Aspek tersebut terdiri atas: kesesuaian tema dengan pengembangan cerita, kesesuaian isi dialog dengan konflik, kesesuaian tokoh dan perwatakan, penggunaan urutan tahapan alur, pemilihan kata dalam dialog unik dan menarik, kesesuaian penggunaan teks samping, ketepatan kaidah penulisan naskah drama, dan keaslian ide. Kemampuan menulis naskah drama meningkat sebesar 36,1\%. Pada siklus I nilai rata-rata siswa adalah 62,9 dan pada siklus II nilai ratarata siswa meningkat menjadi 85,2 dan pada siklus III sebesar 87,1.

\section{Simpulan}

Berdasarkan rumusan masalah, hasil analisis penelitian dan pembahasan penelitian tindakan kelas ini dapat disimpulkan sebagai berikut. Kemampuan menulis teks drama kelas XI SMAN 9 Gowa Kecamatan Somba Opu Kabupaten Gowa setelah mengikuti pembelajaran menulis teks drama dengan menggunakan teks drama sebagai model dalam pembelajaran melalui pendekatan kontekstual komponen pemodelan mengalami peningkatan. Hasil data dari tes prasiklus menunjukkan skor rata-rata kelas sebesar 58,04 dan pada siklus I rata-rata kelas sebesar 67. Hal ini berarti menunjukkan ada peningkatan sebesar 9. Pada siklis II menghasilkan skor rata-rata kelas sebesar 80,2. Hal ini menunjukkan adanya peningkatan dari siklus I ke siklus II sebesar 13,2\%. Jadi terjadi peningktan keterampilan menulis drama dengan pendektan kontekstual pemodelan 


\section{Saran}

Berdasarkan pembahasan dan simpulan di atas peneliti menyarankan agar:

1. Guru bahasa Indonesia dalam pembelajaran menulis teks drama, menggunakan model berupa teks drama supaya dalam proses pembelajaran siswa lebih termotivasi dan antusias, karena siswa secara langsung mengetahui bentuk teks drama sehingga siswa memiliki gmbaran mengenai hal-hal yang terdapat di dalam teks drama. Selain itu, proses pembelajaran pun dapat berjalan dengan lancar karena siswa lebih aktif dan siswa merasa senang mengikuti pembelajaran tersebut.

2. Guru bahasa Indonesia hendaknya menerapkan pendekatan kontekstual komponen pemodelan sebagai alternatif dalam pembelajaran menulis teks drama.

3. Para siswa harus lebih sering berlatih dalam kegiatan belajar mengajar khususnya dalam pembelajaran menulis teks drama sehingga kemampuan menuis siswa dapat meningkat dan dapat menghasilkan teks drama.

\section{Ucapan Terima Kasih}

\section{Daftar Pustaka}

Alfani, D., Harahap, L. A., \& Hutagalung, T. (2012). Pemerolehan Bahasa Pada Anak Sekolah Dasar Di Lingkungan Etnis Batak Mandailing. JURNAL SASINDO (Program Studi Sastra Indonesia FBS UNIMED), 10(1).

Badelah, B. (2021). Peningkatan Kemampuan Menulis Teks Drama Menggunakan Media Cerpen Kelas Viii. E Smpn 2 Sakra Tahun Pelajaran 2020-2021. LEARNING: Jurnal Inovasi Penelitian Pendidikan Dan Pembelajaran, 1(1), 49-62.

Beer, D. F., \& McMurrey, D. A. (2019). A Guide to Writing as an Engineer. John Wiley \& Sons.

Destiana, D. (2019). Keterampilan Berbahasa Menulis Karangan Deskripsi.

Hutagaol, D. N. (2020). Efektivitas Model Tari Bambu (Bamboo Dancing) Terhadap Kemampuan Menulis Naskah Drama Pada Siswa Kelas VIII SMP Negeri 37 Medan Tahun Ajaran 2019/2020.

Hutagaol, K. (2013). Pembelajaran kontekstual untuk meningkatkan kemampuan representasi matematis siswa sekolah menengah pertama. Infinity Journal, 2(1), 85-99.

Indramawan, A. (2021). Group Investigation; Konsep dan Implementasi dalam Pembelajaran (Vol. 1). Academia Publication.

Indrawati, F., Fatimah, A., \& Tricahyani, T. (2021). Meningkatkan Kemampuan Menyimak Anak Usia 5-6 Tahun Melalui Media Flip Chart. Jurnal Penelitian Dan Pengembangan Pendidikan Anak Usia Dini, 8(1). 
Khairi, H. (2020). Peningkatan Keterampilan Menulis Melalu Metode Graphic Organizer pada Pembelajaran Bahasa Indonesia Kelas V MIN 3 Aceh Besar. [PhD Thesis]. UIN Ar-Raniry.

Marwani, I. (2020). Peningkatan Kemampuan Menulis Naskah Drama Menggunakan Model Pembelajaran Kooperatif Tipe Circ Dengan Media Kartu Situasi Khayal Pada Siswa Kelas Vi-B Sdn 1 Beringin Raya. Ksatra: Jurnal Kajian Bahasa Dan Sastra, 2(1), 53-62.

McConnell, C., Conrad, B., \& Uhrmacher, P. B. (2020). Lesson Planning with Purpose: Five Approaches to Curriculum Design. Teachers College Press.

Mufidah, N., \& Rohima, I. I. (2020). Pengajaran Kosa Kata Untuk Mahasiswa Kelas Intensif Bahasa Arab: Vocabulary Teaching for Arabic Intensive Class. Uniqbu Journal of Social Sciences, 1(1), 13-24.

Muyassaroh, Z. (2007). Peningkatan Kemampuan Menulis Teks Drama dengan Pendekatan Kontekstual Komponen Pemodelan pada Siswa kelas VIII E SMP Negeri 3 Ungaran [PhD Thesis]. Universitas Negeri Semarang.

Oflaz, A. (2019). The foreign language anxiety in learning German and the effects of total physical response method on students' speaking skill. Journal of Language and Linguistic Studies, 15(1), 70-82.

Rasyid, R. E. (2020). Higher Order Thingking Skills (Vol. 1). CV Syntax Computama.

Sakubun, M. N. H. D. (2019). Journal of Japanese Learning and Teaching.

Silalahi, R. (2011). Kontribusi Model Pembelajaran Kontekstual Tipe Inkuiri Dalam Meningkatkan Motivasi Dan Prestasi Belajar Siswa Pada Mata Pelajaran Pendidikan Kewarganegaraan. Edisi Khusus, 2, 134-143.

Susanto, S., \& Andik, A. (2020). Penerapan Project Base Learning Dalam Upaya Meningkatan Kemampuan Menulis Teks Pidato Bahasa Jawa Siswa Kelas Ix E Smp Negeri I Gondang Mojokerto Tahun Pelajaran 2019/2020. Jurnal Pedagogi: Jurnal Penelitian Dan Pendidikan, 1(1), 57-66.

Tabelessy, N. (2019). Kreativitas Menulis Karangan Persuasi Siswa SMP. Jurnal Tahuri, 16(2), 35-46.

VERAWATI, F. (2017). Pengaruh Pendekatan Pembelajaran Kontekstual Terhadap Hasil Pembelajaran Pendidikan Agama Islam (Studi di SMPN 2 Pabuaran Kabupaten Serang) [PhD Thesis]. Universitas Islam Negeri" Sultan Maulana Hasanuddin" BANTEN. 
ISSN 2443-3667 (print) 2715-4564 (online)

Wati, H. S., \& Santosa, W. H. (2019). Keefektifan Penggunaan Media Papan Cerita dalam Pembelajaran Menulis Teks Fabel pada Kelas VII MTs Yapi Pakem Sleman Yogyakarta Tahun Pelajaran. Caraka, 5(2), 29-36.

Zainur, F., Irawati, A., Bertha, N., \& Kayla, P. (2020). Efektivitas Metode Shadowing Dalam Mata Kuliah Nihongo Kiso Renshu Untuk Meningkatkan Keterampilan Berbicara Mahasiswa.

Zapata, G. C. (2020). Sprinting to the finish line: The benefits and challenges of book sprints in OER faculty-graduate student collaborations. International Review of Research in Open and Distributed Learning, 21(2), 1-17. 